\title{
Census Tract
}

National Cancer Institute

\section{Source}

National Cancer Institute. Census Tract. NCI Thesaurus. Code C67490.

Relatively permanent statistical subdivisions of a county used by the U.S. Bureau of the Census for purposes of population enumeration. Each tract has a unique identification number consisting of a 4-digit basic number and a 2-digit suffix of the form 1234.56. 